\title{
Peer-assisted learning: a platform for long-term development for both tutors and tutees
}

This article was published in the following Dove Press journal:

Advances in Medical Education and Practice

14 October 2016

Number of times this article has been viewed

\author{
Shiraz Jamshaid' \\ Mohammad Farwana ${ }^{2}$ \\ Faisal Jamshaid ${ }^{2}$ \\ Wasim Jamshaid' \\ Reem Farwana ${ }^{3}$ \\ Sharaf Sheik-Ali ${ }^{4}$ \\ 'Imperial College London, School \\ of Medicine, ${ }^{2}$ Kings College \\ London, School of Medicine, \\ London, ${ }^{3}$ Birmingham University, \\ School of Medicine and Dentistry, \\ Birmingham, ${ }^{4} \mathrm{~B}$ arts and the London \\ University, School of Medicine and \\ Dentistry, London, UK
}

\section{Dear editor}

We read with great interest the perspective of peer-assisted learning (PAL) in medical school by Menezes et al and agree with the high importance placed on PAL. ${ }^{1}$ Its use throughout undergraduate and postgraduate medicine should not be underestimated, as mentioned by Ah-Kee et al, ${ }^{2}$ and is integral in preparing the future teachers in medical education. The lack of formal undergraduate PAL schemes is something that needs to be addressed, as its implementation would help expand the success seen in areas where it is being used. As medical students with a combined total of 10 years of giving and 16 years of receiving PAL teaching over four universities, we would like to share further experience and highlight the positive aspects of PAL that are less commonly noted.

Much like the author highlights, PAL schemes that we have been exposed to, tend to be run by medical student associations or societies. They consist of small group sessions of 4-10 students led by 1-2 senior student volunteers. ${ }^{1}$ The danger, however, with formal introduction of PAL is the compromising of motivation, as students move from volunteer tutors to listed teachers. Indeed, the extracurricular nature of this scheme avoids the highly in demand medical curriculum timetabling, and subsequently becomes a more flexible method of teaching and learning from our experience.

As the author discusses, the ability to teach a medical topic stems from your knowledge and confidence in that particular topic. ${ }^{1}$ Thus, an obvious advantage is the necessary revisiting of material for which you have already been certified. The concept of a "spiral curriculum" in which there is "iterative revisiting of topics" throughout the medical course has been detailed by many medical schools as a relevant way of integrated learning. ${ }^{3}$ Consequently, PAL can be seen to follow the concept of spiral curricula allowing the tutors to revisit and build on topics when teaching tutees.

Since the teachers are commonly students of higher years, pitching the information to the relevant level is well achieved. The ability to share knowledge in an informal and extracurricular environment also enables sharing of advice on time management and life inside and outside of medicine. Such mentoring deems useful in reducing the anxiety levels of medical students involved and improving the use of their time, thus improving career development in the long term. ${ }^{4}$

As the author suggests, the PAL schemes help to bring out many useful qualities in medical professionals - skills that are not commonly taught through a rigid curriculum, but through strong engagement with students having relatable 
experience. ${ }^{1}$ But what is less commonly noted is that through PAL, you are exposed to numerous styles of teaching, which enables the development of your own unique teaching style, having learnt first-hand as to what works well and what does not.

\section{Conclusion}

To conclude, we highly encourage the implementation of PAL schemes, organized by student bodies at an undergraduate level, to supplement both the knowledge of students and improve their mental well-being and ability so that they become better graduate peer-reviewed teachers. In addition, further positive aspects that should be noted are the longterm opportunities provided to tutors through PAL, mainly the revisiting of learnt topics when tutoring students, thus cementing their knowledge.

\section{Disclosure}

The authors report no conflicts of interest in this communication.

\section{References}

1. Menezes A, Burgess A, Clarke AJ, Mellis C. Peer-assisted learning in medical school: tutees' perspective. Adv Med Educ Pract. 2016;7:31-38.

2. Ah-Kee EY, Scott RA, Shafi A, Khan AA. How can junior doctors become more effective teachers? Adv Med Educ Pract. 2015;6:487-488.

3. Harden RM. What is a spiral curriculum? Med Teach. 1999;21(2):141-143.

4. Al-Dubai S, Alshagga M, Manaf M. Mentoring and perceived stress level among private medical students: a Malaysian perspective. Procedia Soc Behav Sci. 2013;93:276-280.

Dove Medical Press encourages responsible, free and frank academic debate. The content of the Advances in Medical Education and Practice 'letters to the editor' section does not necessarily represent the views of Dove Medical Press, its officers, agents, employees, related entities or the Advances in Medical Education and Practice editors. While all reasonable steps have been taken to confirm the content of each letter, Dove Medical Press accepts no liability in respect of the content of any letter, nor is it responsible for the content and accuracy of any letter to the editor.

\section{Publish your work in this journal}

Advances in Medical Education and Practice is an international, peerreviewed, open access journal that aims to present and publish research on Medical Education covering medical, dental, nursing and allied health care professional education. The journal covers undergraduate education, postgraduate training and continuing medical education including emerging trends and innovative models linking education, research, and health care services. The manuscript management system is completely online and includes a very quick and fair peer-review system. Visit http://www.dovepress.com/testimonials.php to read real quotes from published authors.

Submit your manuscript here: http://www.dovepress.com/advances-in-medical-education-and-practice-journal 